\title{
CONSTRUYENDO PATRIMONIO \\ MECENAZGO Y PROMOCIÓN ARTÍSTICA ENTRE AMÉRICA Y \\ ANDALUCÍA
}

GUADALUPE ROMERO SÁNCHEZ (ED.)

Castelló de la Plana, Publicacions de la Universitat Jaume I, 2019, 219 páginas

ISBN: 978-84-17429-60-7

Las financiación, producción e intercambio de objetos artísticos y sus significados entre América y Andalucía es una de las líneas que investiga las complejas relaciones y cruces culturales que, desde el momento de la llegada a América, se fueron forjando en un intenso proceso de ida y vuelta. Este espléndido texto, de cuidada edición y sometido a la evaluación por pares, es fruto de esos trabajos, tan necesarios para desvelar la génesis y presencia de determinados objetos artísticos en el patrimonio cultural de ambos territorios. Guadalupe Romero Sánchez, renombrada investigadora en la materia, es la instigadora y editora de este "Construyendo Patrimonio. Mecenazgo y promoción artística entre América y Andalucía", que, publicado por la Universitat Jaume I, cuenta con el apoyo de la Universidad de Granada y del proyecto de investigación "Relaciones artísticas entre Andalucía y América. Los territorios periféricos: EEUU y Brasil”.

El índice cuenta con ocho capítulos -nueve autoras y tres autores de procedencia internacional- a través de los cuales son analizados y valorados aspectos fundamentales de este proceso de transmisión. Dominado, como no puede ser de otra manera, por la producción de significado y procedencia religiosa, la editora define, no obstante, un marco territorial, tipológico y cronológico muy amplio, contando con el innegable acierto de expandirlo hasta la contemporaneidad en un interesante afán de incidir en la continuidad del relato más allá del periodo colonial.

En este sentido, tomando como referencia el concepto de patrocinio o mecenazgo, el hilo conductor -creemos que de manera acertada- viene dado por la actividad de distintos agentes adscritos a marcos sociales diferentes, lo que permite una visión multifocal y esclarecedora del tema. Así, los textos de Yolanda Fernández Muñoz e Inmaculada Rodríguez Moya se centran en la figura institucional de los virreyes como promotores artísticos. Yolanda Fernández trabaja la figura de Luis de Velasco, Marqués de Salinas, y su vínculo con el arquitecto Francisco Becerra y sus trabajos en el virreinato del Perú. Las obras de la portada 
del palacio virreinal de Lima, el corral de San Andrés y la intensa intervención en la catedral son muestra de ello. Inmaculada Rodríguez, por su parte, desarrolla la labor de Fernando de Torres y Portugal, conde de Villardompardo, virrey del Perú entre 1585 y 1592, de quien desgrana una biografía en la que destaca su labor en el virreinato caracterizada por su buena gestión administrativa y constructiva en la que llegó a emplear parte de su propia hacienda. Hombre al parecer marcado por una fuerte sobriedad religiosa, se preocupó por la ubicación y decoro de la capilla de la familia en la reformada catedral de Jaén, su ciudad natal.

No menos interesante resulta en su aportación a la construcción de las relaciones artísticas entre los dos territorios, la presencia de la figura del indiano como promotor de objetos artísticos, fundamentalmente relacionados con el culto y la devoción a determinadas imágenes y advocaciones. Esta figura, que se expande desde el comerciante enriquecido al noble desplazado al Nuevo Mundo, es tratada, bajo prismas diferentes, por Guadalupe Romero Sánchez, María del Castillo García Romero y Ana Ruiz Gutiérrez. Guadalupe Romero elabora un interesantísimo trabajo que abre caminos poco transitados relacionados con las donaciones de ida y vuelta de los indianos en Andalucía oriental y más concretamente en Granada. Hasta nueve personajes de esa, llamémosle, condición social figuran en su texto como promotores, donantes y transmisores de objetos artísticos que parafraseando a la autora hablan de la aportación americana al proceso de construcción, embellecimiento y dotación de recursos a los espacios religiosos granadinos.

El texto de María del Castillo García se centra en la, hasta ahora oscurecida, presencia de la mujer en los procesos de construcción históricos La autora desvela la labor promotora de María Manuela de Mori, mujer de origen novohispano, que ejecuta en 1764 el testamento de su marido, el lebrijano José de Mora, convirtiéndose en promotora de una parte importante del actual patrimonio cultural de la sevillana Lebrija, origen de un destacado taller de retablistas y escultores. García Romero, afinando la actuación de la indiana, atribuye a su presencia la existencia de un lienzo de la Virgen de Guadalupe en una parroquia de la ciudad.

Ana Ruiz afronta el mecenazgo ejercido por la nobleza a través de la estirpe de los Moreno, familia asentada en Motril durante la repoblación del siglo XV. Tras mostrar la genealogía del apellido, centra su investigación en los hermanos Agustín y Alonso Francisco Moreno Beltrán-Cerrato Ruiz de Castro, el primero de los cuales alcanzó el título de marqués de Valle Ameno en 1740. La figura de Agustín como la del noble inversor en cargos y empleos que llegó a adquirir la capitanía general de Nuevo México, corre paralela a la de su hermano Alonso que fue deán de la iglesia metropolitana de México y gobernador del arzobispado. Si 
ambos, son ejemplo de ese estrato sociológico, también lo son de ese proceso de mecenazgo por cuanto unificaron sus testamentarías y fundaron la capilla de la Virgen de las Angustias de Granada en la catedral mexicana a la que dotaron y ornamentaron.

En este proceso de análisis, no puede dejarse a un lado la fundamental aportación de las cofradías como agentes colectivos de encargos artísticos. Diego Lévano Medina realiza un ejercicio recopilatorio de las inversiones de estas asociaciones limeñas en la promoción artística de la escuela escultórica andaluza. Con un censo de aproximadamente cien cofradías a fines del siglo XVII, reflejo de la estructura de la sociedad limeña (españoles, indios y negros), estas organizaciones dinamizaron en dos fases el mercado artístico limeño. Una primera surge a partir de 1550 a raíz del inicio de las construcciones de las iglesias de las órdenes religiosas y de las capillas de las cofradías, lo que incide, tanto en los encargos como en el desplazamiento de los artistas al territorio peruano. Y una segunda, a partir de mediados del siglo XVII en la que se llevan a cabo labores de mejora, remodelación o mantenimiento de esos espacios religiosos.

En esta misma línea se encuentra el capítulo desarrollado por Adrián ContrerasGuerrero cuyo objetivo es mostrar el funcionamiento del mercado escultórico de Nueva Granada. Contreras articula el texto en función de los generadores de demanda, en los que además de a los promotores religiosos concede una, más que interesante, relevancia a los particulares y sobre todo a una clientela local generadora de producción local. Parafraseando al autor, la condición humilde de Nueva Granada condujo a la importación de obras desde Quito y España, mientras que los artistas locales, sin un marco legal específico, se caracterizaron por su versatilidad en la producción artística y su necesidad de recurrir a fuentes de ingresos paralelas.

Un espléndido colofón del libro, lo constituyen los dos últimos capítulos que se abren a la cronología más reciente en esas relaciones artísticas de América y España. Vinculados a la expansión de la investigación a los territorios periféricos, por una parte, Adriana Vidotte y Adailson José Rui recurren a la fotografía, como tipología artística contemporánea, para incidir en esas relaciones culturales. Ambos descubren y analizan la interesante obra de Pierre Verger, fotógrafo francés y brasileño de adopción, depositada en la Fundación Pierre Verger en Salvador de Bahía y de la que extraen de las aproximadamente mil imágenes tomadas en su viaje por España en 1935, las realizadas en Andalucía, alguna de las cuales se reproducen en el libro. Verger que, al contrario de Cartier-Bresson, consideraba la fotografía como la captación de un instante no buscado sino encontrado o intuido, fue capaz de atrapar ese discurrir del momento andaluz. 
El último capítulo, también en esta línea de las relaciones culturales en la contemporaneidad, está escrito por Hélène Fontoira y Cristina Doménech. Ambas enfocan la idea del aumento de la presencia de la escultura de Luisa Roldán "La Roldana" en las colecciones de Estados Unidos. Superados los prejuicios sobre la religiosidad dramática del barroco español, la presencia de esta artista, ciertamente de rasgos formales más amables, en importantes colecciones como la Hispanic Society o el Metropolitan Museum abre un camino de investigación importante en Estados Unidos. Así, el artículo muestra al proceso de investigación y la genealogía coleccionista de las piezas, así como reflexiones sobre los procesos y criterios de conservación y restauración de la escultura en barro.

Un libro, pues, que, como ya avanzamos, resulta de acertada composición y en el que, además de recoger los avances en la investigación de la línea propuesta, se sugieren nuevas lecturas de ciertos procesos histórico-culturales generados entre ambos territorios.

José Ramón Barros Caneda

Universidad de Cádiz 